\title{
Clarifying Concepts About Homeopathy
}

\author{
Lucio Ramón González García* \\ Assisting professor of the UCM-VC, Cuba
}

Submission: July 05,2019; Published: July 16, 2019

*Corresponding author: Lucio Ramón González García, Assisting professor of the UCM-VC, Cuba

\section{Introduction}

Dear colleagues, it is known by all that the homeopathy has been mistreated and reviled by those from outside and worse still, also for those of inside of that, with its opinions against the medicine and its indifference in the face of science have made it damage. I consider necessary to make some precisions to clarify and to remark some concepts on the homeopathy. Remaining silent without giving to know our ideas and positions, we will never end up influencing positively in the guild and they will follow some per secula seculorum saying incongruities and worse even being inconsistent with the carried out scientific studies, alone to respect to their " professor-icons " located in the Middle Ages, what facilitates that the opponents ridicule and anathematize the homeopathy. Let us begin to clarify some of these concepts using in the appropriate moment some paragraphs of the Theses of Wolf, homeopath belonging to the Central Society of Homeopathy of Germany known also as School of Leipzig and whose members were students and the main collaborators of Hahnemann in the foundation of the homeopathy.

\section{Are we Another Medicine?}

It is well known that we are only a medical therapy and not another medicine not even the new medicine school like erroneously thought at that time the own Hahnemann. The same as the surgery, the allopathy, the immunology, etc. is part of the medicine since we know, and we practice a therapeutic one and we don't apply the medical knowledge in way different to those that are studied in all the Medicine School. That distinguishes the two treatment schools it is the therapy, not the anatomy, physiology, etiology, nosology, compared anatomy, pathological anatomy. We find the knowledge of these matters' indispensable. We consider the homeopaths that think that this matter is dispensable, as fellows that belong to another school, we won't share their merits, neither we will appropriate of the critics that receive $[1,2]$.

\section{Are we Part of the Complementary Medicine?}

We consider that with the previous answer it is defined that the homeopathy is not complementary. It could only be so if the other therapeutic consider each other as complementary one of others. It is in any event an option among the grateful medical therapies $[3,4]$.

Does Have the Organon of the Medicine Written for Hahnemann All the Answers?

We know that it doesn't have all the answers, the text is only a normative one to guide and to channel the thought. Those who consider the possibility that the Organon is certain and it contains all the answers, it is in the field of the faith and not of the science, and that we know the homeopathy is not a religion. Some critics have specified with justice that many extravagant and exclusive ideas of the Organon were not approved by many homeopaths $[1,2]$.

\section{Is the Science A Materialistic Tool Which Only Serves} to the Allopath's?

That is another great fallacy which repeats the approach obscurantist. Is it not science the investigations with methodological and experimental rigor carried out by homeopaths in different places? Also, there is a numberless of great scientists that were idealistic E.g. we have Newton and Mendel. We don't accept the widespread opinion that the medical homeopath can exclude the reflection and trials on the disease, keeping the symptomatic correlation exclusively. To stay in such raw empiricism could be the tomb of the science $[1,2]$.

\section{Should We or Not to Be Up to Date?}

Only an individual without capacity, intelligence and good trial thinks that it he should not be up to date. That attitude is not characteristic of a Doctor. We have the obligation to investigate and to update our knowledge. For some time, the homeopaths have pointed out the tendency of Hahnemann to sustain certain illusions. In a reiterated and independent way, we have announced that we don't share neither we support the absence of scientific achievements, neither we proclaim that only the empiric behaviors are valid in the art of healing. We are reproached when Hahnemann says that one cannot know the interior cause, neither it is necessary, because alone the dynamic causes exist. For us the material and organic substrate of the symptoms is able to know. They say that it doesn't interest 
us the origin and place of the illnesses, but just by the blind and enthusiast critic produces such asseverations as if it were arguments, opposed to the scientific tendency of the homeopathy. To deny completely the investigation of the nature or essence of the illnesses (as Hahnemann inculcates) it is not an article of faith for the homeopaths. The innate desire to investigate the hidden causes, urges to the human mind to make until of the seemingly inscrutable thing, investigation reason $[1,2]$.

\section{Is the School of Medicine Synonymous of Medicine Allopath's School?}

The Medicine School is only the place where the future doctors are formed, and not another thing is a medicine school. What happens is that unfortunately it has not been possible to incorporate in all them the homeopathy like curricular matter and therefore in almost all, the graduate ones alone know of the allopathic therapeutic. The schools of medicine graduate health professionals who choose the therapy they like to use more.

\section{Is It or Not the Allopathy Synonymous of Conventional Medicine?}

Far of being a medicine, the allopathy is a pharmacotherapy or medication based on the medical biochemistry, a department in the building of the conventional medicine or medical science.

If we Make A Mistake when Prescribing, Do we Generate A Suppression or Morbid Metastasis?

To affirm this is not more than a platitude from homeopaths that have not been updated in the biophysical investigations of the homeopathic medication and therefore, they have not been able to discern that that is not possible. Authorities like Hahnemann, Dunham, Nash, neither other grate homeopaths suggested in any moment such a blunder $[3,4]$.

Is It the Activated Water or Another Factor the Responsible for the Pharmacological Activity in the Dil-Agit?

After Jacques Benveniste's works and the corroboration of the same ones for Luc Montagnier consider that that answer is given for the homeopaths that stay fairly informed on the experimentation in homeopathy, the other homeopaths simply have the obligation of being updated for not being obsolete [3-5].

\section{References}

1. Wolf P Paul Wolf 18 Theses. Archive fur Homoopathische Heilkunst (Files of the homeopathic art of healing).

2. Guajardo Bernal G (2014) Homeopathic Foundation. Ed Homeo Sapiens. Mexicali.

3. Guajardo Bernal G (2007) Homeopathic Posology. Third Edition. Ed Ateneos. Mexicali.

4. Guajardo Bernal G (2008) Medical Homeopathy. First Edition. Ed Ateneos. Mexicali.

5. Guajardo Bernal G (2014) Bases of the homeopathy.

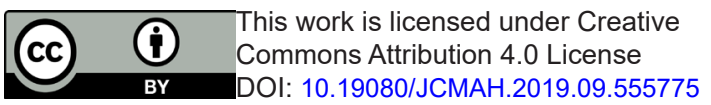

\section{Your next submission with Juniper Publishers will reach you the below assets}

- Quality Editorial service

- Swift Peer Review

- Reprints availability

- E-prints Service

- Manuscript Podcast for convenient understanding

- Global attainment for your research

- Manuscript accessibility in different formats

( Pdf, E-pub, Full Text, Audio)

- Unceasing customer service

Track the below URL for one-step submission https://juniperpublishers.com/online-submission.php 